\title{
Agata Kraińska
}

Uniwersytet Mikołaja Kopernika w Toruniu

e-mail: agata.kraińska@interia.pl

\section{J.S. MILL I G.S. BECKER O RÓWNOŚCI KOBIET I MĘŻCZYZN W SPOLECZEŃSTWIE}

\section{J.S. MILL AND G.S. BECKER ABOUT GENDER EQUALITY IN SOCIETY}

DOI: $10.15611 / \mathrm{e} 21.2016 .3 .29$

JEL Classification: J14, J15, J16, J70, J71

Streszczenie: $\mathrm{W}$ artykule podjęto próbę przedstawienia problemu dyskryminacji kobiet $\mathrm{w}$ aspekcie społeczno-ekonomicznym, uwzględniając poglądy J.S. Milla oraz G.S. Beckera. Praca Milla pt. Poddaństwo kobiet, zaliczana jest do kanonu myśli feministycznej, a Ekonomiczna teoria zachowań ludzkich autorstwa G.S. Beckera pokazuje, że na gospodarkę rynkową wpływ mają różne czynniki, które niekoniecznie są bezpośrednio z ekonomią powiązane. Obaj naukowcy, których poglądy zostały przedstawione w niniejszym artykule, są zdania, że kobiety są ofiarami dyskryminacji. Zarówno J.S. Mill, jak i G.S. Becker uważają, że gorsze traktowanie kobiet negatywnie wpływa na gospodarkę. Zdaniem tych wybitnych i zasłużonych ekonomistów każdy człowiek powinien mieć takie same prawa społeczne, ekonomiczne i polityczne.

Słowa kluczowe: równouprawnienie, społeczeństwo, płeć, dyskryminacja.

Summary: This article attempts to present the problem of discrimination against women in socio-economic aspect, taking into account the views of J.S. Mill and G.S. Becker. Work by Mill, called Serfdom of women, belongs to the mainstream of feminist thought and The economic theory of human behavior by G.S. Becker shows that the market economy is influenced by various factors that not necessarily are directly related to the economy. Both scientists whose views are showed in this article are of the opinion that women are victims of discrimination. Both J.S. Mill, and G.S. Becker believe that the inferior treatment of women has a negative impact on the economy. According to the eminent and distinguished economists, every person should have the same social, economic and political rights.

Keywords: equality, society, gender, discrimination. 


\section{Wstęp}

Zjawisko dyskryminacji społecznej oraz na rynku pracy jest niewątpliwie ważnym problemem grup mniejszościowych XXI wieku. Do najczęstszych powodów gorszego traktowania zalicza się: wiek, płeć, pochodzenie etniczne, kolor skóry czy poglądy polityczne i religijne. Obecnie dużo uwagi w mediach i literaturze poświęca się dyskryminacji ze względu na płeć.

Zjawisko dyskryminacji nie zostało zauważone dopiero w obecnym czasie. Wybitny angielski filozof, politolog i ekonomista XIX wieku - John Stuart Mill - walczył o zwiększenie praw kobiet. Problem gorszego traktowania grup mniejszościowych (w tym także kobiet) był jednym z głównych obszarów zainteresowań noblisty z 1992 roku - Gary'ego Stanleya Beckera, który napisał i obronił doktorat pt.: Ekonomiczna teoria dyskryminacji.

W dziejach teorii ekonomii można spotkać również innych wybitnych ekonomistów, którzy poruszali zagadnienie dyskryminacji, takich jak np.: Platon, Karol Marks czy Arystoteles, który był zwolennikiem panowania mężczyzny nad kobietą. Można zatem sądzić, że problem dyskryminacji ze względu na określoną cechę jest istotnym problemem ludzkości.

Celem niniejszego artykułu jest pokazanie poglądów J.S. Milla oraz G.S. Beckera na temat dyskryminacji kobiet w aspekcie społeczno-ekonomicznym oraz prawnym. Praca Milla pt. Poddaństwo kobiet zaliczana jest do kanonu myśli feministycznej, a Ekonomiczna teoria zachowań ludzkich autorstwa G.S. Beckera pokazuje, że na gospodarkę rynkową wpływ mają różne czynniki, które nie są bezpośrednio z ekonomią powiązane.

\section{Sylwetki J.S. Milla oraz G.S. Beckera}

W różnych dziedzinach naukowych są specjaliści, którzy zajmują się równością wybranych grup w społeczeństwie. Już wśród teorii głoszonych przez starożytnych filozofów można zaobserwować poglądy dotyczące jednakowego traktowania wszystkich, niezależnie od poglądów, pochodzenia czy płci. Jednym z nich był na przykład uczeń Sokratesa - Platon [Mill 1995, s. 296]. Jednakże w przytoczonym artykule nie zostaną opisane poglądy tego wybitnego starożytnego filozofa.

Niniejszy artykuł dotyczy głównie poglądów Johna Stuarta Milla oraz Gary’ego Stanleya Beckera na temat dyskryminacji kobiet.

John Stuart Mill urodził się 20 maja 1806 roku w Londynie i był synem Jamesa Milla [Ludwikowski, Woleński 1979, s. 7]. Ciekawostką na temat tego znakomitego uczonego jest to, że zaliczany jest on do grona najwybitniejszych ludzi, gdyż jego iloraz inteligencji wynosił 190 [Davis 1998, s. 515]. Wychowywany oraz edukowany był przez ojca, który kształtował odpowiednie warunki, aby jego syn mógł zdobywać wykształcenie [Stankiewicz 2007, s. 143]. W wieku zaledwie trzech lat John 
Stuart Mill uczył się już greki oraz arytmetyki. Kiedy skończył osiem lat, zaznajamiał się z łaciną, geometrią, chemią i fizyką. Z kolei jako dwunastolatek oswajał się z logiką i ekonomią. W kolejnych latach kontynuował naukę we Francji. W 1823 roku (w wieku 17 lat) w East India Company z sukcesem robił karierę na stanowisku urzędnika [Berlin 2000, s. 243]. Sposób wychowywania przez ojca nie wykreował w J.S. Millu poglądów religijnych - był on ateistą [West 2004, s. 22; Raeder 2002, s. 65]. Warto dodać, że J.S. Mill był zwolennikiem łączenia interwencji państwa w gospodarkę z leseferyzmem [Bochenek 2010, s. 27], czyli poglądu filozoficzno-ekonomicznego, który głosił wolność jednostki, szczególnie w aspekcie społeczno-ekonomicznym. Angielski uczony, podobnie jak Nassau William Senior, uznawał podział ekonomii politycznej na naukę, która łączyła fakty (prawdy materialne), oraz sztukę, która dotyczyła wartości, czyli sądów normatywnych [Blaug 1995, s. 185]. Tym samym John Stuart Mill potrafił dostrzegać powiązania pomiędzy czynnikami z różnych dziedzin naukowych, takich jak ekonomia, społeczeństwo czy polityka [Landreth, Colander 1998, s. 420]. Dzięki temu, że J.S. Mill pochodził z rodziny ekonomicznej, jego pozycja wśród wybitnych ekonomistów oraz sława podyktowane były nowatorskimi i oryginalnymi koncepcjami. Ponadto dzięki niemu szkoła klasyczna osiągnęła najwyższy poziom [Bochenek 2010, s. 91-92].

Zmarł w 1873 roku [Bochenek 2010, s. 105] (w wieku 67 lat) w Awinionie (Francja) na różę (łac. eryspielas) i został pochowany razem ze swoją żoną Harriet Taylor Mill.

Kolejnym wybitnym naukowcem, o którym mowa w niniejszym artykule, jest noblista Gary Stanley Becker. Urodził się on 2 grudnia 1930 roku w Pottsville (Stan Pensylwania w Stanach Zjednoczonych Ameryki) [Bartkowiak 2006, s. 123]. Kiedy miał pięć lat, jego rodzina przeprowadziła się do miasta Nowy Jork [Misala 2011, s. 209]. G.S. Becker dorastał w znanej dzielnicy Nowego Jorku - na Brooklynie [Glaeser, Shleifer 2014, s. 1233]. W 1951 roku na Uniwersytecie w Princeton zdobył tytuł licencjata nauk humanistycznych (B.A.), a w 1955 roku obronił tytuł doktora nauk ekonomicznych $(\mathrm{PhD})$ na Uniwersytecie w Chicago. Jego praca doktorska nosiła tytuł Ekonomiczna teoria dyskryminacji. Warto dodać, że noblista był studentem Miltona Friedmana - uważanego za twórcę szkoły z Chicago [Glaeser, Shleifer 2014, s. 1233]. W 1957 roku przeniósł się z Uniwersytetu w Chicago do Uniwersytetu Columbia, gdzie trzy lata później został profesorem ekonomii. Warto dodać, że Gary S. Becker współpracował również z takimi wybitnymi ekonomistami, jak Theodore W. Schultz (noblista z 1979 roku) oraz George J. Stigler (noblista z 1982 roku) [Rychlewski]. Ucząc się od najlepszych, G.S. Becker sam został uhonorowany Nagrodą Nobla w dziedzinie nauk ekonomicznych w 1992 roku. Nagrodę tę otrzymał „za zastosowanie analizy mikroekonomicznej w badaniu szerokiego zakresu ludzkich zachowań i interakcji, w tym zachowań nierynkowych"1 [Bartkowiak

${ }^{1}$ Cytat ten pochodzi z publikacji autorstwa R. Bartkowiaka [2006, s. 123]. Treść oryginalna znajduje się natomiast w źródle: [Lindbeck 2016]. 
2006, s. 125]. W dorobku naukowym noblisty wyróżnia się cztery teorie, do których powstania niewątpliwie się przyczynił. Są to [Bartkowiak 2006, s. 127]:

- teoria dyskryminacji mniejszości,

- teoria przestępstwa i kary,

- teoria kapitału ludzkiego,

- teoria rodziny.

Profesor Becker żonaty był dwukrotnie. Jego pierwszą żoną od 1954 roku była Doria Slote, która zmarła po szesnastu latach małżeństwa (w 1970 roku) [Nobel Prize, on-line]. Z tego związku na świat przyszły dwie córki Beckera: Catherine oraz Judy. Dziesięć lat później ożenił się z Guity Nashat, która była historyczką Bliskiego Wschodu i miała dwóch synów Cyrusa i Michaela Claffeya [Hershey Jr., on-line]. Noblista zmarł 3 maja 2014 roku (żył lat 83) w Illinois w szpitalu Northwestern Memorial [Harms, on-line] w wyniku komplikacji pooperacyjnych [Bear 2014, on-line].

\subsection{Poglądy Johna Stuarta Milla o równouprawnieniu kobiet}

John Stuart Mill, jak już zostało wspomniane powyżej, był wybitnym ekonomistą, który w swoich rozważaniach uwzględnił problem gorszego traktowania kobiet. Należy zaznaczyć, że na kwestię równouprawnienia kobiet oraz nadania im prawa wyborczego istotny wpływ miała znana działaczka i od 1851 roku jego żona - Harriet Taylor [Galbraith 1992, s. 132].

Najbardziej znaną pracą J.S. Milla na temat roli kobiet jest niewątpliwie Poddaństwo kobiet, którą napisał już po śmierci żony [Grabowska 2012, s. 189]. Jednakże ekonomista twierdził, że jest jedynie współautorem tej pracy, gdyż to pod wpływem natchnienia żony powstało to dzieło. W kwestii społeczno-politycznej J.S. Mill uważał małżonkę za nieomylnego doradcę i starał się zrealizować jej pomysły w tej dziedzinie [Ludwikowski, Woleński 1979, s. 11].

Jedno z pierwszych zdań, jakie J.S. Mill napisał w rozprawie, pt. Poddaństwo kobiet, były następujące „sądzę, że zasada regulująca stosunek dwóch płci, czyniąc jedną drugiej podwładną w imię prawa, jest zła sama w sobie i stanowi dzisiaj jedną z głównych przeszkód tamujących postęp ludzkości" [Mill 1995, s. 285]. Na podstawie przytoczonego tekstu wyraźnie widać, że już w XIX wieku problem poddaństwa kobiet był krytykowany i uważany za powód hamowania rozwoju ludzkości.

W Anglii w drugiej połowie XIX wieku prawo wyborcze miało zaledwie 30\% dorosłych obywateli. Kobiety oraz $40 \%$ mężczyzn nie mogło brać czynnego udziału w głosowaniu. Zdaniem J.S. Milla taka sytuacja musiała ulec zmianie. Zaproponował zmiany w tej kwestii, ale nadal pewna grupa ludzi była pozbawiona prawa wyborczego. Jego zdaniem każdy dorosły, niezależnie od tego, czy to kobieta czy mężczyzna, kto potrafi pisać i czytać, powinien mieć prawo do czynnego udziału w głosowaniu. W związku z tym, że kobiety stanowiły około połowę populacji angielskiej, J.S. Mill uważał, że wszelkie strategie polityczne wpływają również na nie. W konsekwencji kobiety powinny mieć prawo do głosowania, tym bardziej że 
można przypuszczać, że ogół społeczeństwa będzie oddawać głos na tych, którzy podporządkowują kobiety mężczyznom. J.S. Mill był zdania, że kobiety powinny mieć prawo do głosowania w celu ochrony własnych interesów. Angielski uczony zaznacza również, że brak prawa wyborczego dla kobiet jest tylko jednym z objawów dyskryminacji [Mill 1995, s. 30-31].

W wiktoriańskiej Anglii kobiety nie mogły uzyskać wyższego wykształcenia oraz były wyłączone z możliwości wykonywania pewnych zawodów oraz zajmowania się polityką. Powołaniem prawdziwej kobiety było małżeństwo. Zawierając jednak związek małżeński, niewiasta przestawała być odrębną jednostką. Od momentu zamążpójścia stawała się częścią mężczyzny, a jej dotychczasowy majątek stawał się własnością męża. W czasach współczesnych Millowi kobiety zamężne nie miały prawa zarządzać swoim majątkiem. Tylko nielicznym udawało się zdobyć jakiekolwiek wykształcenie. Z kolei kobiety z arystokratycznych kręgów miały więcej przywilejów, a mając odpowiednie wpływy polityczne oraz pieniądze, mogły robić to, na co miały ochotę - tak jak mężczyźni [Mill 1995, s. 31].

Zdaniem J.S. Milla hipokryzją była opinia zwolenników utrzymywania kobiet w upośledzeniu społecznym. Ich zdaniem takie położenie kobiet nie było poddaństwem, gdyż nie były one sprzedawane w niewolę. Jak zauważa Mill, gospodyni domowa to jedyna legalna forma niewolnictwa w ówczesnej Anglii. Jego zdaniem zamężne kobiety znajdowały się w gorszej sytuacji niż niewolnice, gdyż niewolnica miała prawo odmówić współżycia ze swoim właścicielem, a kobieta nie mogła odmówić swojemu mężowi. Ponadto dzieci nie należały do matki, lecz do ojca. W dziewiętnastowiecznej Anglii kobieta, która była prześladowana przez męża, mogła zgłosić sprawę do sądu i nawet usłyszeć wyrok korzystny dla siebie, ale po rozprawie była odsyłana z powrotem do domu, do męża [Mill 1995, s. 31]. Zatem nasuwa się pytanie, czy wyrok korzystny dla poszkodowanej miał jakiekolwiek uzasadnienie w praktyce, skoro kobieta musiała wrócić do męża, który ją maltretował.

Warto również wspomnieć, że John Stuart Mill o prawa kobiet nie walczył wyłącznie za pośrednictwem publikacji. Będąc członkiem Izby Gmin, czynnie udzielał kobietom wsparcia odnośnie do uzyskania przez nie praw wyborczych. Zgłosił także poprawkę do Drugiej reformy wyborczej Disraelego w tej sprawie. Niestety odrzucono ją większością głosów (196 z 269 posłów) [Grabowska 2012, s. 189]. W książce R. Ludwikowskiego i J. Woleńskiego pt. J.S. Mill można przeczytać, że ,postawienie jednak kwestii na forum parlamentu zaktywizowało działalność angielskich emancypantek; powstały liczne kobiece stowarzyszenia (Primrose League, Women's Liberal Federation, Women's Liberal Unionist Federation), które miały pierwsze zwycięstwa na polu organów lokalnych" [Ludwikowski, Woleński 1979, s. 134]. Nawet sam J.S. Mill był aktywny w ruchu sufrażystek, a co więcej został liderem London National Society for Women's Suffrage [Grabowska 2012, s. 189].

W swoim największym dziele, dotyczącym praw kobiet, oprócz przyznania niewiastom praw wyborczym, zabiegał także o jednakowy dostęp kobiet i mężczyzn do 
większości zawodów i urzędów na podstawie wolnej konkurencji. Zauważał również problem zamężnych kobiet, które są finansowo uzależnione od mężów i mają utrudniony dostęp do separacji i rozwodów [Grabowska 2012, s. 189].

John Stuart Mill w swoich rozważaniach zasugerował, że skoro równouprawnienie płci nie jest akceptowane przez społeczeństwo w ówczesnej Anglii, to należy zrobić eksperyment. Nikt bowiem nie wie, jaka jest różnica pomiędzy możliwościami obu płci (znane są możliwości fizyczne, z których jasno wynika, że mężczyźni są silniejsi). Zdaniem Milla to, co jest naturalne dla kobiet i mężczyzn, można określić tylko wtedy, gdy da się wszystkim jednakową możliwość rozwoju i wykorzystania swoich możliwości w sposób swobodny. W eseju J.S. Milla można przeczytać, że przyczyny poddaństwa kobiet wynikają ze sposobu ich wychowywania. Każde dziecko płci żeńskiej było wychowywane tak, aby w przyszłości było posłuszne i słabe emocjonalnie, co umożliwiało mężczyznom kontrolowanie połowy ludzkości [Mill 1995, s. 298].

\subsection{Gary Stanley Becker o dyskryminacji w społeczeństwie}

Gary Stanley Becker w swoich rozważaniach dużo uwagi poświęcał zachowaniom nierynkowym, które mają istotny wpływ na ekonomię. Jego największym dziełem poświęconym właśnie zachowaniom ludzkim jest Ekonomiczna teoria zachowań ludzkich [Becker 1990]. W pracy tej można przeczytać o zastosowanych metodach analizy ekonomicznej w odniesieniu do bardzo szerokiej problematyki zachowań ludzkich, które bardzo daleko odbiegają od tradycyjnie przyjętych obszarów zainteresowań ekonomii. Noblista był pierwszym ekonomistą, który tak bardzo rozszerzył zakres analizy ekonomicznej [Sadowski 1995, on-line].

Warto wspomnieć, że problem dyskryminacji w działalności gospodarczej G.S. Becker wprowadził do ekonomii neoklasycznej. Jednakże amerykański ekonomista kierował się przemyśleniami z lat czterdziestych XX wieku, którymi zajmował się szwedzki ekonomista, polityk i socjolog laureat Nagrody Banku Szwecji im. Alfreda Nobla w dziedzinie ekonomii w 1974 roku - Gunnar Myrdal [Bartkowiak 2006, s. 129].

Według G. Beckera na dyskryminację wybranych grup społecznych na rynku wpływają osobiste uprzedzenia zarówno pracodawców, jak i pracowników, konsumentów, nauczycieli czy przedstawicieli władz. Grupy mniejszościowe nie mają możliwości proponowania różnych kwalifikacji w odpowiedniej ilości, ponieważ mają ograniczoną liczebność grupy, co sprzyja również zjawisku dyskryminacji. Z tym niewątpliwie powiązany jest brak inwestycji w edukację i szkolenie grup dyskryminowanych, co w dalszej kolejności prowadzi do niższej wydajności, a co za tym idzie - niższych dochodów. W ten sposób na rynku pracy tworzy się dobór o charakterze pozarynkowym [Bartkowiak 2006, s. 129].

Noblista w swojej książce Ekonomiczna teoria zachowań ludzkich przedstawił współczynnik rynkowej dyskryminacji MDC (Market Discrimination Coefficient). Zgodnie z założeniami porównywane grupy pracowników są tak samo produktyw- 
ne i wzajemnie zamienne, a niedyskryminujący pracodawca to taki, który dokonuje zatrudnienia pracownika w sposób losowy i wypłaca takie samo wynagrodzenie za taką samą wykonywaną pracę [Sedlak\&Sedlak, on-line]. Współczynnik ten ukazuje, o ile procent dochody grupy dyskryminowanej są niższe od dochodów grupy dyskryminującej. Wzór przedstawiający współczynnik rynkowej dyskryminacji wygląda następująco:

$$
\mathrm{MDC}=d / W_{f},
$$

gdzie: MDC - współczynnik rynkowej dyskryminacji; $d$ - różnica w płacach pomiędzy grupą niedyskryminowaną a grupą dyskryminowaną; $W_{f}-$ wynagrodzenie ludzi z grupy dyskryminowanej. Jeżeli wynik jest większy od zera, wówczas występuje zjawisko dyskryminacji. Jeśli z kolei wynik będzie mniejszy od zera, to ma miejsce protekcja lub nepotyzm. Brak dyskryminacji występuje wtedy, gdy współczynnik będzie równy zeru [Johnes, Sapsford 1996, s. 10-25]. Rozważania G.S. Beckera dotyczyły głównie dyskryminacji rynkowej ze względu na kolor skóry, jednakże do powyższego wzoru można podstawić dane dotyczące również innych grup mniejszościowych.

Noblista w swojej pracy dowiódł, że dyskryminacja praktykowana przez określoną grupę zawsze prowadzi do obniżenia jej dochodów oraz dochodów grupy dyskryminowanej² [Becker 1990, s. 45].

G.S. Becker w swoich badaniach podważył teorię marksistowskich poglądów, według której dyskryminacja jest korzystna dla osób dyskryminujących. Becker zauważył, że pracodawca, który rezygnuje z zatrudnienia człowieka dobrze wykwalifikowanego do pracy wyłącznie ze względu na określoną cechę (płeć, kolor skóry, pochodzenie czy poglądy polityczne i religijne), traci okazję zatrudnienia wydajnego pracownika. W związku z tym zjawisko dyskryminacji jest kosztem dla osoby dyskryminującej. Gary S. Becker udowodnił, że w branżach konkurencyjnych zjawisko dyskryminacji nie występuje aż tak często. Dzieje się tak, gdyż firmy, które gorzej traktują wybrane grupy społeczne, tracą udziały na rynku na korzyść tych firm, które nie prowadzą polityki dyskryminującej. Udokumentował również, że w branżach silniej kontrolowanych i tym samym mniej konkurencyjnych częściej dochodzi do gorszego traktowania ludzi ze względu na posiadanie przez nich określonej cechy (kolor skóry, płeć, wiek itp.) [Library Economics Liberty, on-line]. Według jego teorii konkurencja przyczynia się do zmniejszenia objawów dyskryminacji [Saylor.org, on-line].

G.S. Becker zauważył również, że wiele kobiet będzie rezygnować z pracy, gdyż niska płaca oraz wyższe wynagrodzenie ich mężów będzie czynnikiem demotywu-

2 Więcej na ten temat można przeczytać w G.S. Becker, Ekonomiczna teoria zachowań ludzkich, Państwowe Wydawnictwo Naukowe, Warszawa 1990, gdzie na te rozważania został poświęcony cały rozdział 2. 
jącym do podjęcia lub kontynuowania przez nie pracy zawodowej [Becker 1990, s. 347]. Można zatem wnioskować, że dyskryminacja ze względu na płeć na rynku pracy może nie występować zupełnie, ponieważ to same kobiety rezygnują z pracy zawodowej.

\section{Zakończenie}

Z przeprowadzonej analizy literatury przedmiotu wynika, że problem dyskryminacji kobiet nie jest tylko problemem XXI wieku. John Stuart Mill - syn Jamesa Milla - już w XIX wieku wspierał emancypację kobiet. Uważał, że każdy ma takie samo prawo do brania czynnego udziału w życiu politycznym. Zwrócił również szczególną uwagę na fakt, że kobiety zamężne nie mogą rozporządzać swoim majątkiem i są podporządkowane mężowi. Według Milla jest to przejaw niewolnictwa jawnie przyjętego i tolerowanego przez państwo, którym rządzą mężczyźni. John Stuart Mill był jednym z pierwszych mężczyzn, który popierał ruchy kobiece. Na jego opinię w tej kwestii miała wpływ jego przyjaciółka, a później żona - Harriet Taylor Mill, z którą napisał rozprawę pt.: Poddaństwo kobiet - krytykę ówczesnego rządu i zasad przyjętych przez społeczeństwo na temat dyskryminacji kobiet.

Gary Stanley Becker - noblista w 1992 roku - krytykował różne traktowanie grup mniejszościowych. W swoich rozważaniach zajmował się szczególnie dyskryminacją czarnoskórych przez białych ludzi, ale gorszej sytuacji kobiet również poświecił czas w swoich rozważaniach. Jego zdaniem branża, w której ma miejsce dyskryminacja ze względu na określoną cechę (w tym też ze względu na płeć), traci bardzo dużo w stosunku do branż, w których takie zjawisko nie ma miejsca.

Obaj naukowcy, których poglądy zostały przedstawione w niniejszym artykule, są zdania, że kobiety są ofiarami dyskryminacji. Zarówno J.S. Mill, jak i G.S. Becker uważają, że gorsze traktowanie kobiet negatywnie wpływa na gospodarkę. Zdaniem tych wybitnych i zasłużonych ekonomistów każdy człowiek powinien mieć takie same prawa społeczne, ekonomiczne i polityczne.

Rozważania na temat równości w społeczeństwie wymagają jeszcze głębszej analizy, zważywszy na fakt, że ofiarami dyskryminacji mogą być różne grupy społeczne, a nie tylko kobiety. Ponadto problem gorszej sytuacji kobiet poruszali również inni teoretycy, których poglądy nie zostały przedstawione w tymże opracowaniu.

\section{Literatura}

Bartkowiak R., 2006, Gary Stanley Becker, [w:] pod red. nauk. J. Kalińskiego, Poczet Doktorów Honoris Causa Szkoly Głównej Handlowej w Warszawie, Oficyna Wydawnicza Szkoły Głównej Handlowej w Warszawie, Warszawa. 
Bear S.K., Nobel-prize Winding economist Gary Becker dead AT 83, http://articles.chicagotribune. com/2014-05-04/news/chi-nobel-winning-economist-gary-becker-dead-20140504_1_economicsnobel-memorial-prize-princeton-university (24.03.2016).

Becker G.S., 1990, Ekonomiczna teoria zachowań ludzkich, Państwowe Wydawnictwo Naukowe, Warszawa.

Berlin I., 2000, Cztery eseje o wolności, Wydawnictwo Zysk i S-ka, Poznań.

Blaug M., 1995, Metodologia ekonomi, Wydawnictwo Naukowe PWN, Warszawa.

Bochenek M., 2010, Studia varia o ekonomii i ekonomistach, Wydawnictwo Polskiego Towarzystwa Ekonomicznego. Oddział w Toruniu, Torun.

Davis N., 1998, Europa. Rozprawa historyka z historia, Wydawnictwo Znak, Kraków.

Galbraith J.K., 1992, Ekonomia w perspektywie. Krytyka historyczna, Państwowe Wydawnictwo Ekonomiczne, Warszawa.

Gary S. Becker - Biographical, http://www.nobelprize.org/nobel_prizes/economic-sciences/laureates/1992/becker-bio.html (24.03.2016).

Glaeser E.L., Shleifer A., 2014, Gary Becker (1930-2014), Science, vol. 344, 6189.

Grabowska B., 2012, Feminizm Johna Stuarta Milla, Kultura i Edukacja, nr 1.

Harms W., Nobel-winning scholar of economics and sociology, 1930-2014, http://news.uchicago. edu/ article/2014/05/04/gary-s-becker-nobel-winning-scholar-economics-and-sociology-1930-2014 (24.03.2016).

Hershey Jr. R.D., Gary Becker, 83, Nobel Laureate, Dies; Applied Ecoomics to Everyday Life, http:// www.nytimes.com/2014/05/05/business/economy/gary-s-becker-83-nobel-winner-who-applied-economics-to-everyday-life-dies.html?_r=0 (24.03.2016).

Johnes G., Sapsford D., 1996, Some Recent Advances In the Economic Analysis of Discrimination, International Journal of Manpover, $\mathrm{nr}$ 1(17).

Landreth H., Colander D.C., 1998, Historia myśli ekonomicznej, Wydawnictwo Naukowe PWN, Warszawa.

Library Economics Liberty, Gary Stanley Becker, http://econlib.org/library/Enc/bios/Becker.html (26.03.2016).

Lindbeck A., The Sveriges Riksbank Prize In Economic Sciences In Memory of Alfred Nobel 1969-2007, http://www.nobelprize.org/ nobel_prizes/economic-sciences/articles/lindbeck/ (dostęp: 24.03.2016).

Ludwikowski R., Woleński J., 1979, J.S. Mill, Państwowe Wydawnictwo Wiedza Powszechna, Warszawa.

Mill J.S., 1995, O rzadzie reprezentatywnym. Poddaństwo kobiet, Wydawnictwo Znak, Kraków.

Misala J., 2011, Gary Stanley Becker, [w:] Nagrody Nobla w dziedzinie ekonomii 1969-2009, red. J. Misala, Wydawnictwo Politechniki Radomskiej, Radom.

Raeder L.C., 2002, John Stuart Mill and the Religion of Humanity, Wydawnictwo University of Missouri, Missouri.

Rychlewski E., Charakterystyka sylwetki profesora Garego S. Beckera, profesora ekonomii i socjologii The University of Chicago, USA, Szkoła Główna Handlowa w Warszawie, http:/uczelnia.sgh. waw.pl/pl/uczelnia/informacje/dhc/Strony/becker_sylwetka.aspx (24.03.2016).

Sadowski Z., 1995, Ocena dorobku naukowego Profesora Gary Beckera w zwiazku z postepowaniem o nadanie tytułu doktora honoris causa Szkoły Głównej Handlowej, Szkoła Główna Handlowa, Warszawa, http://uczelnia.sgh.waw.pl/pl/uczelnia/informacje/dhe/Strony/becker_ocena.aspx (26.03.2016).

Saylor.org, Economics explains discrimination in the labour market, http://www.saylor.org/site/ wpcontent/uploads/2012/06/ECON303-8.2.1.pdf (26.03.2016).

Sedlak\&Sedlak, Teorie dyskryminacji płacowej, https://badaniahr.pl/biblioteka/art/id/68/Teorie_dyskryminacji_placowej\# (30.03.2016). 
Stankiewicz W., 2007, Historia myśli ekonomicznej, wyd. 3 zm., Polskie Wydawnictwo Ekonomiczne, Warszawa.

West H.R., 2004, An Introduction to Mill's Utilitarian Ethics, Wydawnictwo Cambridge University Press, Cambridge. 